\title{
Events and Texts: The Prologues and Epilogues of the Arbury Plays
}

A compelling element of the four plays in Arbury 414 is their framing speeches. By contrast the revised, neater version of The Humorous Magistrate found in the Osborne collection contains neither prologue nor epilogue. Of the four plays in the Arbury collection, The Emperor's Favourite includes only a prologue, while the other three plays feature both prologues and epilogues. Ghismonda and Guiscardo, a tragedy based on Boccaccio's Decameron 4.1, contains an eighteen line prologue and a twelve line epilogue; The Twice Chang'd Friar, a comedy based on Decameron 4.2, contains a twenty-two line prologue and a fourteen line epilogue; The Emperor's Favourite, a Roman tragedy that draws from Juvenal's and Suetonius's descriptions of Nero's favourite Crispinus, contains a sixteen line prologue; and The Humorous Magistrate, an original comedy, features a twenty-four line prologue and a thirteen line epilogue. ${ }^{1}$ These speeches are reproduced in full in the appendix.

Framing texts like those attached to the Arbury plays have garnered little critical attention. Recent scholarship has begun to reverse this neglect and has challenged traditional assumptions that framing speeches are merely uncomplicated introductions and conclusions to the only material of real interest. Douglas Bruster and Robert Weimann maintain that these speeches often go beyond the 'conventional and supplicatory' 2 and serve, in fact, as 'interactive, liminal, boundary-breaking entities that negotiated charged thresholds between and among, variously, playwrights, actors, characters, audience members, playworlds, and the world outside the playhouse'. ${ }^{3}$ Tiffany Stern, studying the speeches in printed dramas that would have been performed in London on the stages of the commercial theatres, suggests that prologues and epilogues were a 'temporary form' that convey 'just how local and detailed the critiques [of plays] could be.. In the most recent and comprehensive study of prologues and epilogues, Brian Schneider argues for the 'extraordinary experimentation to which prologues and epilogues were 
subjected in the period $1580-1660$ '. 5 These speeches are used, he contends, 'to enunciate their [playwrights'] diverse ideas on referentiality, theatricality, audience participation and expectation and authorial competence'. ${ }^{6}$ While these critics refer mainly to prologues and epilogues in professional, urban theatres, their observations will provide a useful starting point for my own consideration of the nuanced sense of locality and audience evoked by the Arbury speeches.

I hope to show that prologues and epilogues of this amateur dramatist are as significant as those addressed by Bruster and Weimann, Stern, and Schneider; the Arbury plays feature 'enunciations' as complex as those made by plays of the professional theatre. I will argue first that the Arbury prologues and epilogues betray evidence that these plays were indeed performed and performed on special occasions for an intimate gathering in a non-urban location, in a space that Julie Sanders calls the 'potent domain of the estate' in the early modern period. 7 I will then suggest that the author of these plays had a precise vision for their continuing life on stage and page beyond their first, occasional performances. This vision bespeaks a vibrant literary community in rural early modern England. Thus, I follow Bruster and Weimann's supposition that prologues and epilogues 'serve as culturally significant sites' where the entanglement and divergence of 'text' and 'event' is expressed. ${ }^{8}$ The Arbury framing speeches embed details of the play's occasionality and textuality, details about the events of performance and the poetic durability of the plays beyond these occasions.

The Arbury framing texts reveal a familiarity with the genre in that they are 'conventional and supplicatory' in nature. The prologue of each play appeals primarily to an intelligent playgoer and asks that he or she appreciate the playwright's skill, while at some level employing the humility topos with the suggestion that the play and/or the performance is undeserving. The speeches often describe this type of spectator as someone who has 'clear eyes' or who is capable of being 'well discerning'. All plays, however, with the exception of the rather utilitarian prologue of The Emperor's Favourite, worry about an audience reacting negatively to the play. In that event, they predict a person will 'hiss' at the play, fail to understand it, dislike, or censure it. All of the epilogues request approval or outright applause, only modestly of course, and ask that the plays' faults be excused. These conventional tropes, however, do not tell the full story of the function of these speeches and the eloquence with which they articulate a sense of the plays' occasionality and poetic durability. 
Tiffany Stern writes that prologues and epilogues were 'focused, purposeful, and occasion-specific: the first and last in a series of playhouse "gifts".? They are, she argues, the means by which playwrights fit their plays to a particular audience and therefore 'make the critical audience more likely to accept a play. ${ }^{10}$ If the material proved successful, she suggests, the prologue and epilogue may well have been dropped from later performances or printed texts. As Margaret Jane Kidnie observes, the mere presence in the Arbury plays of prologues and epilogues point to a playwright 'attuned to live performance.'. ${ }^{11}$ These speeches point to the likelihood that the plays were indeed performed and that they were as invested in suiting their material to a specific occasion and audience as commercial, urban plays.

With the exception of The Humorous Magistrate, the Arbury prologues and epilogues use the first person plural to address the audience on behalf of the author, who is consistently mentioned in third person. There is no evidence that the speeches were designed for a specific character in the play, as with Rosalind's speech at the close of As You Like It or the more general character of the Chorus in Henry V. In the case of The Humorous Magistrate and The Twice Chang'd Friar, the prologues concentrate, rather seriously, on the duty of the audience to appreciate the playwright's craft. It would be difficult to imagine a main character from these comedic plays, such as the inept Justice Thrifty in The Humorous Magistrate, educating the audience in how to behave. The speeches, then, seem to be written for a character outside the play who speaks on behalf of his fellow actors. In The Twice Chang'd Friar, the author's concerns and expectations are detailed so explicitly and at such length that it is not difficult to imagine the playwright himself, perhaps John Newdigate, playing the role of prologist. The speech outlines what the author 'intends' and 'expects' from the audience and also declares that the author is 'confident' that his friends will understand these intentions. In Ghismonda and Guiscardo, the prologue worries 'we shall faile' if it is 'a fault to shew you how a story / May be preseru'd' (1-4). The Ghismonda And Guiscardo prologue states that it is better to see a show than have 'one tong' read a tale aloud, thus suggesting that a group of actors would perform the play for the benefit of an audience that should welcome the performance to verify the value of many tongues over one.

While the prologue to The Humorous Magistrate does not refer to the author or speak in first person, it does imply a specific occasion for the performance it introduces. The speech begins by describing how a tragedy adheres to and departs from its historical sources. 'So strict a method', the prologue 
continues, 'the solemnity / Of this day doth disclayme' (8-9). No evidence remains to suggest what 'this day' might have been or the nature of the 'solemnity' that marked it. A solemnity could refer to any ceremonial gathering, from a funeral to a feast, although the fact that The Humorous Magistrate is a light comedy confirms the event must have been celebratory. The play features several marriages and ends with Justice Thrifty, the comically absurd main character, ushering his neighbours to the wedding of his daughter Constance. Contance's bridegroom admits that the lovers delayed the ceremony of the wedding until 'the dayes solemnitye / might be grac'd $\mathrm{w}^{\text {th }}$ the $\mathrm{p}^{\mathrm{r}}$ sence of $\mathrm{yo}^{\mathrm{r}}$ friends' (3456-7). ${ }^{12}$ The prologue's reference to the 'solemnity' of a particular day has resurfaced at the end of the play. Could the play have been part of an entertainment for friends who gathered, like Thrifty's neighbours, to celebrate a marriage at Arbury Hall? The answer to this question remains unresolved at present, but the mention and echo of a 'solemnity' offers tantalizing evidence of the play as part of a rural, domestic celebration with the manor house serving as both ceremony site and stage.

While the language of the Humorous Magistrate framing speeches calls attention to the play's association with a particular event and audience, the paper on which the play was written might indicate that at least one of the speeches was added to the play at a different time (or place?). According to Kidnie, the page featuring the Humorous Magistrate epilogue bears a watermark that does not match the rest of the play's watermarks, an anomaly, she says, that 'may indicate that this epilogue was a late addition to the manuscript. ${ }^{13}$ If the Humorous Magistrate epilogue were indeed added at a later date, it would support Stern's belief that such speeches were not permanently attached to plays and were instead 'occasion-specific', added and dropped as events and audiences dictated. ${ }^{14}$ The unexpectedly sombre tone adopted by The Humorous Magistrate's epilogue raises the possibility that it was added after the play was first performed. It would be difficult to imagine a comic play that celebrates several marriages concluding with a discussion like the one found in the epilogue:

So great things end; the maiestie of Kings

Hath not the aduantage of inferior things

But in the glorious way to ruine, all

The pomp of a maiestick funerall

Being but oblivious prologue. 
This momento mori produces an odd shift in tone. Can a play so light-hearted that it contains a dance and song by a Shepherd King and ends happily with a series of marriages fittingly conclude with the phrase 'so great things end'? In fact, nothing in the play's epilogue supplies incontrovertible proof that it was originally written for The Humorous Magistrate. ${ }^{15}$ The bleak message of the deterioration of kingship in the epilogue may fit well, however, with the growing discord between the king and parliament in the late 1630s, the time of the writing of the Arbury The Humorous Magistrate. While the disjunction between the play's and epilogue's tones argues against the same performance occasion for both, the epilogue's observation of the decay of worldly glory (the 'maiestie' that Charles was trying and failing to maintain) indicates its suitability for a performance occasion in the late 1630s or early 1640s. The possibility that the epilogue was written after the rest of the play or not even written specifically for the play supports, rather than undermines, the idea that the framing speeches are markers of performance occasions and are not permanent fixtures of the text.

Stern's notion of the framing speech as a 'gift' given to an audience by a playwright is particularly relevant to the Arbury plays as many of them imply that the playwright is a host, the playgoer is a guest, and the play is a courteous offering passed between the two. The epilogue to Ghismonda and Guiscardo explains his task to the audience:

But you whose goodnes names you noble freinds

I come to let you know our author sends

You store of thanks, and greeues his tragedie

Did not deserue the gracefull courtesie

You did him looking on it; Yet he protestes

You are more wellcome then to greater feastes

And you will please him much if your hands say

You are delighted with his tragick play.

The epilogue describes the play-going experience as a kind of feast (though the speech does so modestly by calling attention to 'greater feastes') and the author as the host of this celebration. This metaphor would have been particularly appropriate if the author of the play, John Newdigate, staged it before an audience of friends at Arbury Hall. Many rural estate performances capitalized on the parallel between host/guest and playwright/audience. Sanders describes how household entertainments in the late $1620 \mathrm{~s}$ often placed 'heavy emphasis on food and gift giving' and incorporated 


\section{Amy Scott}

these traditions into the dramatics themselves. ${ }^{16}$ The epilogue's reference to 'feastes', then, provides a hint that the play may have featured in an occasional celebration hosted by the playwright and attended by his close friends and family. The play itself, conceptualized as a gift, was simply one symbolic gift among the many material gifts that the guests would have received. The pairing of figurative and literal gifts in a performance diminishes 'any clear distinction between real and "staged" households', a distinction that was often blurred in domestic theatrical events in the Caroline period, according to Sanders. ${ }^{17}$

Ghismonda and Guiscardo's epilogue promotes the idea that the playwright and audience feel mutual respect for each other. The audience exhibits 'gracefull courtesie' by watching the play, and the playwright offers them 'store of thanks' and 'more wellcome' in return. The convivial tone extends even to the request for applause, when the audience members have the chance to 'please' the playwright by registering their own delight with the play. Something more than the mere conventional flattery of the audience by the playwright may be taking place. Could the insistently hospitable tone of this speech indicate a closer relationship between playwright and audience than would have existed in a London playhouse? Perhaps the playwright had first hand knowledge of his audience's qualities and therefore could be certain of their 'goodnes'.

The prologue to The Twice Chang'd Friar announces that 'The free born authour in this play intends / Not to please any but selected friends' (1-2). The idea that the author has chosen the play's spectators may also provide further evidence for the intimacy between playwright and audience that marks the household theatrical. The epilogue's reference to 'selection' could be read, then, as a reference to the playwright's invitation of guests to his estate; an audience for these plays would likely have been populated by kindred and acquaintances of the playwright. Many of these texts, nevertheless, refer to playgoers whom the speakers fear may not understand the play or may react negatively to it. The Twice Chang'd Friar's prologue acknowledges that, though the playwright aims to please only friends,

least some other iudementes should despaire

They could not vnderstand a word, his care

Hath stoop't to their capacities, \& will

Enfeeble powerfull lines that their low skill

May haue some feeling of 'hem. 
What is remarkable about these lines is that they treat those 'other iudgementes' rather tenderly. They address, I would suggest, not ill-tempered, rough playgoers who watched plays from the pit at the Globe (playgoers who would freely 'hiss' their displeasure) but rather people who want to understand the play and 'despaire' if they cannot. There is a sense of familiarity with the less skilled members of the audience here, just as there is when the speech refers to the playwright's friends. The playwright demonstrates 'care' for those with 'low skill', and the prologue later adds that the playwright's 'carefull feare / Bowes and intreats' the appreciation of his 'first nam'd freinds' (19-21). These friends have been, according to the prologue, 'selected' and thus they are likely the guests of the host/playwright: his peers. The term 'care', used to address both the perceptive and dull binds the disparate audience together. The prologue's reference to an audience of diverse capacities and the geniality with which the playwright treats this group can be accounted for by Sanders's suggestion that household theatricals were written for 'a mixed audience of local people, family members, and household servants, as well as dignitaries and visitors to the region'. ${ }^{18}$ The Arbury prologues and epilogues address just this kind of mixture in their gracious attention to playgoers of vastly different levels of understanding.

Ghismonda and Guiscardo's prologue, however, entertains the possibility that its audience will act like a playhouse audience: 'tmay be' it concedes, 'you will hiss / At our kind of expression' (10-11). The prologue imagines an audience that, like the audience in the professional theatres, is not necessarily bound by the host/guest dynamic and the courtesy it requires. The 'hiss' came to stand for an audience's negative reaction to a performance, as is shown in the everyday discourse of some theatrical characters themselves. Sometimes the 'hiss' is used to condemn a poor acting performance, rather than simply to show distaste for the play in general. In Merry Wives of Windsor, Mistress Page says to Mistress Ford in reference to her upcoming performance to deceive Falstaff, 'If I do not act it, hiss me' (3.3.33). ${ }^{19}$ In a series of sermons published in 1614, Thomas Adams notices that if an actor 'shall pla<y> some Emperour, or part of obseruation vnworthily, the spectators are ready to hisse him off'. ${ }^{20}$ The prologue therefore calls attention not only to the value of the author's writing, but also to the quality of the actors' performance, something the speech terms their 'expression'. It is difficult to imagine an audience of friends and guests of the playwright/host 'hissing' their disapproval of the quality of the acting, however. The fear of a vocally disruptive audience could be a comic reminder to the audience of 
what they are not: unruly, censorious, and unfriendly. After all, at the close of this same play, the epilogue emphasizes the 'goodnes' of the audience composed of 'noble freinds'. The conventional worry that an audience will react badly, therefore, when expressed in the domain of the domestic, amateur drama only reaffirms the innate gentility and outward geniality of most of the spectators.

The playwright's solicitous 'care' for his audience in the Arbury framing speeches culminates in the epilogue to The Twice Chang'd Friar, where the playwright expresses concern for the physical discomfort his audience might experience after sitting through a play. 'If your vneasie seats haue tyr'd you so', he surmises, 'You're glad to leaue 'em' (1-2). The playwright is particularly sensible of the effort that the audience's investment in the play has required. Like a good host, the playwright feels responsible for making that investment worthwhile. Sanders points out that household theatricals 'required of their audiences an intensely active mode of engagement that saw them at various times in the production melting in and out of a specific awareness of their surroundings. ${ }^{21}$ The reference to 'tyr' $d$ seats' might even refer to the quality of seating offered to those who watched household theatricals. It is difficult to imagine an audience composed of servants, guests, visitors, and dignitaries all comfortably seated. The epilogue uses the present tense, addressing audience members as if they are leaving their seats at the moment of his speaking. The epilogue could even be acknowledging the possibility that when the spectators left their seats they did not necessarily leave the space of the performance. Because the place of performance was also the domestic space, an audience could feasibly begin to stir, circulate, eat, or exit the room as the epilogue speaks. Could the epilogue have anticipated the natural transition from performance to party? The Twice Chang'd Friar epilogue conveys a sense of the 'intense engagement' described by Sanders, which is marked by the audience's awareness that the performance is one part of a larger entertainment. Such engagement foregrounds the audience members' place-ness - they are not necessarily rooted in the space of performance and, even before the play ends, can ease their tired bodies by returning to the space of the larger domestic entertainment. The experience of play-going is also enfolded into the words of the play itself so that the site of performance is part of the performance; the audience's weary bodies seem to have priority over the bodies that have crossed the stage or the body of the epilogist. The speech, then, serves as a point of transition from the site of performance to the world beyond the play. Schneider suggests that the epilogue can begin to 
'return the audience to everyday reality' and therefore 'blurs the distinctions between onstage and offstage.'22 In the case of household performances, the site of performance is the same as the site of the everyday, and so this distinction is even more indefinite. To 'leave' the performance requires a figurative departure from the play rather than a literal departure from a playhouse.

Schneider observes that prologues and epilogues 'seek to define their own audience, an audience which appears torn between the desire for spectacle and the repeated requests of playwrights for the spectator to pay attention to the words of the play'. ${ }^{23}$ Indeed, the Arbury speeches consistently ask their audiences to become part of the artistic process by acknowledging the playwright and his pen and then asking spectators to think of themselves as readers of the play-text. Stern speculates that prologues and epilogues were designed to inform the audience that 'alteration ... was allowable on this occasion' and that they were 'emerging as "cutters" of the play at least if not more. ${ }^{24}$ The involvement of the audience in the shaping of the play would have been more intense if the play were performed for a circle of friends who shared literary and artistic interests. Kidnie and Sanders, both informed by the work of Virginia Larminie on the Newdigates, describe John Newdigate III's access to this kind of circle. It is enough to say here that Newdigate was a 'theatrically literate man, who in his regional home, was part of an equally vibrant literary and theatrical network'. ${ }^{25}$ According to Sanders, the Arbury plays may have been 'passed around and possibly altered to suit each specific occasion' ${ }^{26}$ The absence of the prologue and epilogue in the Osborne version of The Humorous Magistrate might indicate this very process of tailoring. Stern suggests that prologues and epilogues 'advertise a play ripe for reformation and change, while a play lacking them appeared to have been audience-tested and approved'. ${ }^{27}$ The Arbury framing speeches seem to invite the interventions described by Sanders and Stern. As Owen Stockden observes in this issue, John Newdigate corresponded regularly with Gilbert Sheldon and received advice from him about his literary ventures. A marginal note in the Arbury Humorous Magistrate records an opinion of a particular speech by a 'Dr. S', most likely a reference to Gilbert Sheldon, who received a doctorate in 1634. The presence of commentary points to a lively circulation of literary works of the very kind that marked the trading of texts between Newdigate and Sheldon. The prologue of Ghismonda and Guiscardo, furthermore, asks the literate, skilled spectator to act like a reader of poetry: 


\section{if a man}

[Thates] Able and $\wedge^{\top}$ well ${ }^{\top}$ discerning please to scan

Our lines like verses foot by foot, we will

To such a Artist, gladly submitt our skill.

It is entirely possible that Newdigate references his tendency to ask literate friends to read his plays and provide feedback on them. At the very least, Ghismonda and Guiscardo's prologue asks the audience not only to watch the play but to hear its language and, moreover, listen to the play as critically as a fellow artist reads a written work. The 'very presence of a Prologist', as Schneider perceptively argues, 'usually alone on stage, delivering a speech to herald the play, would naturally alert the audience to listen to the words'. ${ }^{28}$ Ghismonda And Guiscardo's prologue equates 'lines' of the play with 'verses' of a poem, thereby redefining spectators as readers. The implication that the play can be read like a work of poetry offers a suggestive link to John Newdigate, who collected and wrote poetry himself. Deep respect defines the playwright and audience relationship implied here, one that could conceivably gesture to the esteem in which Newdigate held Sheldon and vice versa.

The epilogue to The Humorous Magistrate similarly focuses on the play as poetry. I have raised the possibility that the speech was written after the rest of the play, perhaps not written for this play at all; nonetheless, the speech emphasizes that the audience's task is to be equally impressed by the words and sights that together produce an affective theatrical experience. 'Poetrye', the epilogue says, is 'one step short of immortalitye' (7-8). It concludes the speech by stating that 'The pen lookes to be canoniz'd that wrought / This miracle vpon your eye $\&$ thought' (13-14). The epilogue ostensibly asks for applause here and yet it also requests that the audience approve of the writing (by way of the allusion to the instrument of the pen). Words and sight intertwine densely in this final couplet. The pen 'lookes' and the playgoer must evaluate the play's effect on his or her vision and 'thought'. The pairing of the eye with thought gestures to the connection between performance and text, specifically the way in which a spectacle cannot be understood apart from the effect it has on audience members and what they 'think' of it. When the play passes from the spectator's eye to the spectator's thought, it moves from the impermanent occasion of the performance to the text now in the memory of the audience, which, in the case of the Arbury plays, may also have circulated as a material object beyond the moment of performance. 
I have failed to mention The Emperor's Favourite thus far. It contains only a prologue and approaches its task in a more practical, less theoretical way than its counterparts in the Arbury miscellany. Even this utilitarian speech, however, has something to say about the way the audience must watch the play. It explains,

The storye's Romane $\&$ he that can but call

To mind th' expressiue lines of Iuuenall

Repeats Crispinus pride $\&$ must confesse

His incest there describ'd.

The playwright assumes his audience can recall reading Juvenal but, at the same time, seems to chide this group for having knowledge of a form of satire so 'expressiue' or powerful in its invective that it has the power to taint readers, rendering them as corrupt as the subject about which they read. If, as Siobhan Keenan persuasively argues in this issue, the playwright uses Crispinus as a parallel to the duke of Buckingham, the threat that the reader might 'repeat Crispinus pride' is charged indeed. Yet the playwright has clearly used Juvenal to inform his plot and asks the audience to recall these satires as a way of validating the inclusion of Crispinus's incest in the play. ${ }^{29}$ The playwright might be performing a bit of satire himself, exaggerating a conservative belief that a reader could be corrupted simply by reading Juvenal's work. While the rural theatrical may have been considered more traditional and less Juvenalian than its urban counterparts, perhaps this particular rural theatrical challenges this assumption by exaggerating and thereby mocking a conservative, non-urban perspective. Because John Newdigate frequented London playhouses, he may not have been immune (or wanted to be immune) to the often biting humour associated with the London stage. The audience is enfolded into the controversy and must 'confesse' that it recalls the incest described by Juvenal. Those attending the performance help the playwright by validating the content of the play but must wonder whether this validation has implicated them in a crime. The fate of the play-text, like the fate of Juvenal's own satires, must lie in the hands of audience members and whether or not they are willing to risk 'repeating' the offenses of the material that they read.

Kidnie suggests that the two versions of The Humorous Magistrate, three versions of Ghismonda And Guiscardo, and 'extensive marginal markings' in The Twice Chang'd Friar offer evidence of 'a lively scene of creative production 
and transmission of dramatic texts. ${ }^{30}$ The spirit of this creativity and transmission is processed in the epilogue to The Twice Chang'd Friar:

there's none of you but know

That haue a child, you loue to see it clipt

In dandling armes, $\&$ if the authour slipt

Into a fault, because his actiue pen

Begott this child, \& 'tis the loue of men

To wish their heires long-liu'd he hopes you'l please

T'excuse his errour.

The playwright's literary potency is described in a way that makes it a shared power: audience members are reminded of their own children and, therefore, their own fertility. The structure of this address to the audience - 'there's none of you but know' - mirrors the structure of The Emperor's Favourite's prologue and its address to 'he that can but call / To mind'. In both instances, the playwright reveals the extent of his knowledge about his audience, which is a way of incorporating its experiences and knowledge into the experience of play-going. This theatrical experience makes the forms of creative activity possible in a domestic space (reproduction, 'clipping' or holding a child) counterparts to the writing of a play; a playwright familiar with his audience would be confident making the assumption that they have children and feel indulgent towards them. The speech elaborates on the common metaphor of text as child by suggesting that the playwright is 'tied' to his effort as closely as a parent embraces a child 'In dandling armes'. Remarkably tender, this image repeats the theme of authorial 'care' that marks the play's prologue so heavily. In that prologue, the playwright expresses care for all of his audience members - those with high and low capacities. Here in the epilogue, the speaker asks the individuals making up the audience to remember their own acts of care for their children and to use these memories as inspiration to treat the playwright and his play gently. The reference to the 'actiue pen' that writes the play might supply the opportunity for a bawdy innuendo, but this speech accomplishes much more than a ribald joke. The playwright only accesses his full potency when the audience, likely known intimately by the author, becomes a group of fellow care-takers of the play. When the playwright asks the audience to excuse the play's errors, he does so not because he simply wants applause but because he hopes the play will be 'long-liu'd'. The playwright thus envisions a continued life for his play beyond the occasion of performance, and the audience determines how long this life will last. 
The Humorous Magistrate's prologue revels in the particular occasion of performance that allows a playwright 'spacious liberty' from censure (28). It is something of a joke that this spaciousness is afforded by the theatrical experience that takes place in the household, a much more confined and more amateur arena than the playhouses of London. The household theatrical would have evaded the censorship applied frequently to commercial plays. Perhaps the playwright humorously suggests that the play, while unsophisticated and therefore worthy of censure in many respects, is strangely powerful because it operates beyond the urban centre and thus cannot be contained by the censors. The prologues and epilogues of the Arbury miscellany plays describe the 'intense' forms of engagement the household theatrical offered guests, family members, servants, and visitors. The emphasis in these speeches on a specific occasion and the playwright's exertion of care for a seemingly intimate audience maps out the domestic domain in which the plays were performed. References to the play as an occasion and a piece of writing reveal a playwright who looks to his audience to develop his craft and makes use of the 'spacious liberty' that an audience of close friends provides.

\section{Appendix}

The Emperor's Favourite

Prologue.

The storye's Romane, $\&$ he that can but call

To mind th'expressiue lines of Iuuenall

Repeats Crispinus pride \& must confesse

His incest there describ'd, \& his excesse

His low state rais'd to height, the Emperour

His sole aduancer $\&$ his fauourer.

Sueton $\&$ others shew the passages

That fill the other scenes, $\&$ we professe

To walk by their direction. You shall see

Tigranes fate twice chang'd, the maiestie

Of Tiridates shaken, \& reuiu'd

Againe by plots crosse layd, \& so contriu'd

The deeds disgrace the actors, euery man

That is this way a politian 
Shame payes at last; The play will let you know

At large their riseing, \& their ouerthrow.

\section{Ghismonda and Guiscardo}

The Prologue.

If't be a fault to shew you how a story

May be preseru'd longer in memory

Then if one tong alone had told a tale

Our expectation's crost, $\&$ we shall faile

Of hauing courteous censure; yet ner'theless

All that haue cleare ey'd iudgements, will confess

He merits more, that shewes acutely how

Ghismonda did for Guiscard, (to keep the vow

Which she'd brauely made,) then to heare this

Absurdly told. But 'tmay be you will hiss

At our kind of expression. O take heed

They that doe so will [make] 'cause' his head to bleed

Thates Priscian to them. Yet if a man

[Thates] Able and $\wedge^{\top}$ well ${ }^{1}$ discerning please to scan

$\mathrm{O} u \mathrm{r}$ lines like verses foot by foot, we will

To such an Artist, gladly submitt our skill

And prostrate all our labours at his feete

Whose patience shewes himselfe to be discreet.

Epilogue.

$\mathrm{O} u \mathrm{r}$ play is ended and your expectation

Tak'n vp with that which some mens approbation

Scornes to be giuen to; we do scorn so much

To vnderprize ourselues as think of such.

But you whose goodnes names you noble freinds

I come to let you know our authour sends

You store of thanks, and greeues his tragedie

Did not deserue the gracefull courtesie

You did him looking on it; Yet he protestes

You are more wellcome then to greater feastes

And you will please him much if your hands say

You are delighted with his tragick play.

Finis. 
The Humorous Magistrate

Prologue

Sad stories are the ground work tragedie

Selects to build $\wedge$ 'on': a well ver'st eye

In works of graue historians onely can

See how the skill of a tragedian

Doth prosecute particulars, how farr

His imitation can be regular

And where it leaues the bookes authority.

So strict a method the solemnity

Of this day doth disclayme, \& to be free

From censure takes such spacious liberty

As will not be subordinat to sence

Of any but a [cleare] 'strong' intelligence

In which a modest ingenuity

Claymes share $\&$ fauour, tis humility

To recognize $\&$ challenge. Doe but referr

Things to their apt relations, challenger

Becomes a vanquisht prisoner, $\&$ the man

That was thus humbled, shall triumph againe

Vpon vnable censurers; the fate

Of playes lyes thus, nor is't vnfortunate

To giue some taste dislike, the publique stage

Is free to all, but ominous presage

Rises from iudgement, which can onely be

The [clea] cleare discerner of abilitye.

Epilogue

So great things end; the maiestie of Kings

Hath not aduantage of inferiour things

But in the glorious way to ruine, all

The pomp of a maiestick funerall

Being but obliuious prologue. Can a play

But of two howers life suruiue those gay

Dorned high built tropheies? Poetrye

(But one step short of immortalitye)

Knowes more, thinks less, yet in a modest way

Concludes her yongest son hath in the play 
Spoke sence to some mens wonder. If there be In this strange age impossibilitye

The pen lookes to be canoniz'd that wrought

This miracle vpon your eye $\&$ thought.

\section{The Twice Chang'd Friar}

Prologue.

The free born authour in this play intends

Not to please any but selected friends.

Yet least some other iudgementes should despaire

They could not vnderstand a word, his care

Hath stoop't to their capacitie, \& will

Enfeeble powerfull lines that their low skill

May haue some feeling of 'hem,: \& since he

Hath chang'd high thoughts into humility

Onely for their aduantage, he expects

They should be modest out of those respects

Concern themselues; for 'tis a greater praise

In silence to admire how pens can raise

Things to a loftie pitch, \& let them rest

In that high station which their worth express

Their own; then offer to depose a straine

From it's great height, whose braue transcendent vaine

Sits on a supreme throne, where their dull eies

Cannot discern its strong abilities.

His first nam'd freinds he's confident will beare

With this digression, to whom his carefull feare

Bowes $\&$ intreats their liking which once granted

Will shew, they mist not any thing they wanted

Epilogue

If your vneasie seats haue tyr'd you so

You're glad to leaue 'hem, there's none of you but know

That haue a child, you loue to see it clipt

In dandling armes, \& if the authour slipt

Into a fault because his actiue pen

Begott this child, \& 'tis the loue of men

To wish their heires long-liu'd he hopes you'l please 
T'exuse his errour, which is a disease

Of loue to his own offspring, \& so ties

Him to be thus indulgent. If your eies

Be weary and your eares $\&$ other parts

You may release 'hem, \& crown our deserts

If your applausiue hands vouchsafe to shew

You grace the authour as he honours you.

Exit.

\section{Notes}

I would like to thank Mary Polito for her unfailing support and guidance.

1 The plays are found in Arbury Hall ms A414 in the library of Arbury Hall, Nuneaton, Warwickshire. A microfilm of the Ms is available in wCro, Newdigate Family Papers, M.I. 351/3, Item 20. The Emperor's Favourite appears on ff 145-194, Ghismonda and Guiscardo on ff 77-102v, The Humorous Magistrate on ff 104-143, and The Twice Chang'd Friar on ff 196-229v. The line numbers of the speeches are my own addition in the appendix and are not references to line numbers of any published edition of the plays.

2 Douglas Bruster and Robert Weimann, Prologues to Shakespeare's Theatres (New York, 2004), 2.

3 Ibid, ix.

4 Tiffany Stern, Documents of Performance in Early Modern England (Cambridge, 2009), 83, 91.

5 Brian Schneider, The Framing Text in Early Modern English Drama (Farnham, Surrey, 2011), 2.

6 Ibid, 10.

7 Julie Sanders, Cultural Geography of Early Modern Drama, 1620-1650 (Cambridge, 2011), 5.

8 Bruster and Weimann, Prologues, ix.

9 Stern, Documents, 92.

10 Ibid.

11 Margaret Jane Kidnie, 'Near Neighbours: Another Early Seventeenth-Century Manuscript of The Humorous Magistrate', English Manuscript Studies 13 (2007), 205.

12 This line also appears in the Osborne version of The Humorous Magistrate.

13 Kidnie, 'Near Neighbours', 189. 


\section{Amy Scott}

14 Stern, Documents, 92.

15 The theme of the rise and fall of temporal glory, however, mirrors the prologue's interest in the rise and fall of the fortunes of a play.

16 Sanders, Cultural Geography, 114.

17 Ibid, 115.

18 Ibid, 121.

19 William Shakespeare, Russ McDonald (ed.), The Merry Wives of Windsor (London, 2002).

20 Thomas Adams, The Deuills Banket Described in Foure Sermons (London, 1614), 338.

21 Ibid, 121.

22 Schneider, Framing Text, 6.

23 Ibid, 149.

24 Stern, Documents, 91.

25 Sanders, Cultural Geography, 111. See Kidnie, 'Near Neighbours', 205-7. The work they refer to is Virginia Larminie, Wealth, Kinship and Culture: The SeventeenthCentury Newdigates of Arbury and Their World (Woodbridge, 1995).

26 Sanders, Cultural Geography, 116.

27 Stern, Documents, 82.

28 Schneider, Framing Text, 71.

29 Crispinus attempts to seduce his sister-in-law in the play.

30 Kidnie, 'Near Neighbours', 204. 